\title{
THE BENEFICIAL ROLE OF SURVEYS IN THE INVESTMENT ANALYSIS FOR PUBLIC BUILT CULTURAL HERITAGE CONCESSIONS
}

\author{
C. Boniotti \\ Department of Architecture, Built Environment and Construction Engineering, Politecnico di Milano, Milan, Italy - \\ cristina.boniotti@polimi.it
}

KEY WORDS: Conservation, Valorization, Management, Public-Private Partnership, Concession, ICT

\begin{abstract}
:
Cultural heritage concession has increasingly been adopted as part of public-private partnership agreements in situations where the public administration itself proves to be unable to manage its own cultural heritage. Compared to other public-private agreements, such as sponsorships, concession operations are more complex in nature and require that all private parties involved commit themselves long-term. On the one hand the private partner should estimate costs and revenues in a precise way, which is even more difficult for historic buildings, and be responsible for both ordinary and extraordinary maintenance. On the other hand, the public entity should conceive some legal protection schemes aimed at ensuring the property's correct management on part of the private partner. Therefore, some continuous and preventive conservation activity is in essence mandatory.

In these kinds of operations, a refined survey can allow more precise quantitative and qualitative valuations along the entire process: starting from the launch of the call for tenders, where GIS systems can provide descriptive contents, to the definition of detailed investment analysis by the private partner, as well as the management stage, where the implementation of asset management information systems such as BIM tools will allow for quicker and more efficient monitoring and surveillance by the public partner.
\end{abstract}

\section{CONCESSION}

\subsection{Concession as a public-private partnership}

The public-private partnership (P3) is a procurement form combining design, build (construction or restoration), but also management components under a single contract between public and private bodies (Martin, 2016b: p. 1). It represents a long-term collaboration between public and private entities aimed at realizing public duties (Cori, Paradisi, 2011: p. 41) and allocates risks, rewards, and responsibilities to the partner (the government or the contractor) best able to manage them (Macdonald, Cheong, 2014: p. 15).

P3 usually includes various contractual agreements, which can vary on the basis of the field they belong to and on the basis of each national legislation. This term's significance is currently subject to heavy debate and being criticized to the point that P3 is seen by some as little more than a politically handy language game because it is used in order to promote local political objectives (Hodge, Greve, 2010).

Among the different financing agreements, concession is generally considered a Design-Build-Finance-Operate-Maintain (DBFOM) instrument of P3 (Martin, 2016a: p. 199). Thus, in this case the contractor designs, builds, finances, and operates a public work. Please note that in the cultural heritage field the building stage is replaced by the conservation stage (Rypkema, Cheong, 2012: pp. 13, 14).

Considering that governments typically use different procurements and contracts for each of the aforementioned stages of the process, concession allows contractors to be more involved not only in the decision making, but also in the following heritage site management. Concession might well lead to the creation of a financing model based on the competition between private investors fixing buildings and heritage assets, delivering cultural and environmental services within areas of historic relevance and enjoying a share of revenue consistent with the risk they have born.
Cultural heritage concession has increasingly been adopted as part of public-private partnership agreements. In the Italian context, even the Decree of the President of the Council of Ministers No. 171 of August 29, 2014, commonly referred to as the Franceschini Reform and amending the organization of the Ministry of Cultural Heritage and Activities, mentioned concession as a possible solution in situations where the public administration itself proves to be unable to manage its own cultural heritage.

Compared to other public-private agreements, such as sponsorships, concession operations are more complex in nature and require that all private parties involved commit themselves long-term. Among the positive outcomes of this specific financing arrangement we ought to mention a lesser degree of asset degradation, the inclusion of new adequate intended uses, an increase in socio-economic value in turn capable of triggering urban regeneration processes, and the fostering of adequate and efficient conservation and fruition strategies as well as private investment flow and local income.

In these kinds of operations, a refined survey can allow more precise quantitative and qualitative valuations along the entire process: starting from the launch of the call for tenders, where GIS systems can provide descriptive contents, to the definition of detailed investment analysis by the private partner, as well as the management stage.

\subsection{Definition of concession of valorization in the Italian context}

Among the various types of concession, in the Italian context the State Property Agency itself, i.e. the Demanio Agency, conceived the specific public-private partnership tool of the concession of valorization a first-ditch effort.

In fact, and even though the majority of publicly listed cultural heritage sites is managed by the Ministry of Cultural Heritage and Activities and Tourism, part of the public listed cultural heritage is nonetheless under the purview of the Demanio 
Agency, also known as the Artistic Historic Demanio and consisting of approximately 4,000 buildings, $50 \%$ of which being intended for government use with the rest being vacant and available.

Considering that in the early 2000s valorization was mostly aimed at performing divestitures and that these kinds of buildings can generally not be divested in the light of the public property's being deemed as one of the fundamental components deserving protection, in 2006 the Agency started taking into account a novel means of valorizing them. However, very few pieces of Artistic Historic Demanio-owned real estate were eventually sold and all of them are still under protection in full compliance with the current legislative framework.

As an alternative to divestiture programs, the Agency conceived a new instrument capable of generating income through properties unavailable for sale. The so-termed ordinary concession, as defined in the Consolidated Text on State Accounting Standards and in the Decree of the President of the Republic of Italy No. 29613 of September 2005 regulating the criteria and modalities of the concession for the use and lease of real estate belonging to the State, is limited to a short-term period of 19 years at most. Thus, the Agency suggested that a tool be instated which became known as concession of valorization. Considering that listed assets command that the private sector institutions participating in the partnership sustain the burden of significant investment, the need for some return on investment warrants that the management phase be of a longterm nature (Manzo, 2017). Therefore, and pursuant to Demanio Agency's recommendations, Article 3-bis of Law No. 410 of November, 232001 was added in order to define the concession of valorization and ensure greater consideration of the interest of private sector institutions (Agenzia del Demanio, 2013).

More specifically, Law No. 410 of November, 232001 concerns urgent provisions for the privatization and valorization of public real estate, and the development of mutual real estate investment funds. Article 3-bis "Valorization and use of real estate for economic purposes by either concession or lease" states that:

1. Publicly-owned real estate as identified within Article 1 can be granted to privates through concession or lease and in exchange of consideration in order to regenerate and reconvert it by means of interventions of rehabilitation, restoration, or refurbishment. The introduction of new intended uses is foreseen as well, directed to carry out economic activities or service activities for citizens, without prejudice to the provisions of the Cultural Heritage and Landscape Code, Legislative Decree No. 42 of January 22, 2004 and subsequent amendments.

2. The Ministry of Economy and Finance - the Demanio Agency can convene one or more local authorities meetings or promote programme agreements to submit for approval initiatives for the valorization of properties provided for in this Article.

3. A rate equal to $10 \%$ of the rent shall be remitted to the Municipalities concerned by the procedure referred to in clause 2 , for the entire duration of the concession or lease. If expressly provided in the call for tenders, an amount not lower than the $50 \%$ and not more than $100 \%$ of the construction fee, due pursuant to Article 16 of the Consolidated Text on Building Regulations, has to be paid to the Municipalities, for the execution of the works necessary for the redevelopment and reconversion. This amount is paid by the concessionaire or the lessee upon issue or effectiveness of the building permit.

4. The concessions and the leases referred in this Article are assigned through a public and open procedure, for a period of time commensurate with the achievement of the economic-financial balance of the initiative and, in any case, not exceeding fifty years.

4-bis. At the end of the period of time foreseen by the concessions and leases referred to this Article, the Ministry of Economy and Finance - Demanio Agency, once verified the achievement of the purpose of redevelopment and reconversion of assets, recognizes to the lessee/concessionaire the pre-emption right for the purchase of the asset at the market price, in situations where there are no needs for use for institutional purposes.

Of course, the long-leasehold property and right of superficies would be equally suitable to provide for long-term building use time spans of up to 99 years. However, a long debate has resulted relative to this assignment of right's assimilation to a sales agreement and its applying to cultural heritage. As a matter of fact, a concession of valorization does not constitute an actual right and, unlike in the case of a right of superficies, it does not allow for the concessionaire to use the asset as a source of financial leverage (Manzo, 2017).

\subsection{Potentials and limitations of concession of valorization}

Among the positive outcomes of this specific financing arrangement as adopted by the Demanio Agency vis-à-vis its cultural heritage we ought to mention:

\section{- A lesser degree of asset degradation.}

- An increase in private investment flow and socioeconomic values in turn capable of triggering urban regeneration processes as well as local income.

- The inclusion of new and adequate intended uses. Compatibility should be the sole criteria informing the choice of new intended uses for a concession's built cultural heritage site. No restrictions should thus apply as to the type of intended use. What matters is that the cultural heritage at issue be salvaged and kept in optimal shape (Della Torre, 2016).

- The fostering of adequate and efficient conservation and fruition strategies. As to the latter issue, concession operations allow for making deals regulating opening times and the conditions for public access. In fact, and after the Article defining the concession of valorization went into force, the Cultural Heritage and Landscape Code was amended itself in order to ensure an asset would be available for access and use by the general population. By virtue of the regulations currently in force and concerning the duty to allow for public access, any restoration project will thus have to provide for adequate spaces for public use and fruition by including this provision into the concession contract itself (Manzo, 2017).

For example, the wing of the Royal Villa in Monza currently subject to concession to a private firm may be visited either for a fee or even free of charge on given occasions (Moioli et al., 2018). Even the Ministry of Cultural Heritage and Activities and Tourism granted a capital grant (contributo in conto capitale) to a private actor involved in a private cultural heritage conservation operation in exchange for once-a-year access by the general public (Della Torre, 2016). 
At the same time, and in the case of listed properties, the concession is subject to authorization by the Ministry of Culture Heritage and Activities and Tourism.

Among other things, we ought to mention an option provided to concessionaires, which may acquire "their" piece of property at the end of the concession of valorization period as identified in clause 4-bis of Article 3-bis.

After the introduction of the concession of valorization with Article 58 of the Decree-Law No. 112 of June 25, 2008, the use of the concession of valorization was extended to all local authorities. Therefore, it became an instrument suitable for adoption in the entire public real estate sector (Manzo, 2017). Please note that this opportunity is expressly mentioned under the title of "privatization".

\section{THE BENEFITS OF SURVEYS IN THE INVESTMENT ANALYSIS}

\subsection{Main components of a concession}

In essence, the three main components of a concession are the concession fee, the investment, and time. They are mutually correlated and strongly depend on analyses based on data sourced from surveying.

\subsection{The public sector: definition of the concession fee}

When considering the adoption of a concession, a government needs to conduct a thorough value-for-money analysis, which is aimed at justifying the choice of a P3 tool as opposed to traditional procurements by ensuring an "optimal combination of benefits and costs in delivering services users want" (World Bank Group, 2019). As value-for-money analysis requires both qualitative and quantitative assessments, an exact survey is paramount to making some correct evaluations.

The call for tenders may start with a public consultation directed at assessing investor and specialized operator interest and collecting suggestions aimed at optimizing the procedure itself. A call for tenders will require both a business and management plan, both of which aimed at identifying optimal real estate investment opportunities and assessing each management approach's cost/revenue profile. The tendering procedure could also take advantage of GIS systems providing descriptive data. GIS can support heritage site description and inventory making, and yield information such as listing, planning goals, historical maps and designs, previous surveys, photographs, orto-photo images, sizes, materials, and diagnostic tests outcomes, all of which is especially useful during the predesign stage (Heras, Vandesande, Cardoso, Van Balen, 2014: p. 66; Baratin, Bertozzi, Moretti, 2014: p. 75; Acacia, Casanova, Dal Bò, 2014: pp. 227-228).

Based on the aforementioned evaluations, the subsequent P3 contract needs to properly define the concession fee to be paid by the contractor.

After a restoration has been completed, a public entity should nonetheless conceive some legal protection schemes aimed at ensuring the property's correct management on part of the private partner. Of course, conservation activity supervision in longer-term concessions will be more likely to be affected by organizational and conservation policy-related changes. Therefore, the implementation of asset management information systems such as Building Information Modeling (BIM) tools will allow for quicker and more efficient monitoring and surveillance by the public partner.
Once the concession has expired, the public body will have to ensure that a given piece of cultural heritage has been conserved in a fashion optimal and pursuant to ordinary public real estate management law provisions. As the typical duration of a restoration initiative amounts to 20-25 years, some continuous and preventive conservation activity is in essence mandatory. In this perspective, the asset information model needs periodical updating throughout its life cycle, possibly by both skilled technicians and remote monitoring systems (Ciribini, Mastrolembo Ventura, Paneroni, 2014: p. 2). The model should provide not only quantitative data, but also qualitative information allowing for performance target and/or output requirement assessment.

\subsection{The private sector: definition of the investment}

As the contractor provides the all or a substantial portion of the financing, the concession warrants that both a business and a management plan be defined to tell real estate investments apart from revenues and management-related costs. "The contractor must recover its design and build costs, plus its financing costs, plus its operating and maintenance costs, plus its profit margin over the length of the contract term" (Martin, 2016a: p. 202), in order to protect the investment.

Thus, during the pre-design stage, an investigation aimed at collecting the data needed for assessing a project's economic sustainability and technical feasibility should be conducted. It allows for carefully evaluating risks and valorization opportunities. Information quality is the basis for understanding a building's actual value. Among the various analyses to be developed at this stage, the cost $\&$ revenue analysis is useful for a first return-on-investment estimate. It merges two different kinds of technical knowledge that are often considered as individual entities, namely the technical and economic/financial ones. The more detailed and specific this analysis, the better a valorization initiative's outcome.

During the design and works execution stages, the cost \& revenue analysis and risk assessment must be continuously updated and perfected. Indeed, the objective is to define them as precisely as possible. The management skills should integrate the design ones, as the BIM approach fosters. On the basis of the information model, BIM-based analyses can provide accurate bill of quantities fostering economic comparisons (Ciribini, Mastrolembo Ventura, Paneroni, 2014: p. 9).

A first attempt directed to these objectives and developed in the cultural heritage field was the HBIM implemented for the restoration of the Basilica of Santa Maria di Collemaggio in L'Aquila. The HBIM resulted from the laser scanner survey is an interoperable tool supporting the project, the structural modeling and simulation, and the economic management of conservation activities (Brumana et al., 2014; Oreni et al., 2014; Brumana et al., 2017; Brumana et al., 2018).

In addition, during the management stage, the concession contracts at issue typically provide that the concessionaire be responsible for both ordinary and extraordinary maintenance. Therefore, the private partner should estimate costs and revenues in a precise way, which is even more difficult for historic buildings. Please consider that the management stage itself may vary greatly depending on one's intended use of choice (as for instance, in the case of opting for a luxury hotel as opposed to a hostel). The asset information model can be used in order to implement the conservation plan, which provides data related to localization of technological elements, their state of conservation, monitoring of the structure, and localization, typologies and urgencies of interventions. The conservation plan is a management tool endowing owners and 
concessionaires with information useful to control costs and set valorization strategies over time. It is also conceived for the exchange of data between the different actors, such as operators, practitioners, supervisors, etc. (Benatti, Borgarino, Della Torre, 2014: pp. 19, 24).

\subsection{Time}

P3s are generally long-term contracts, which can last thirty, forty, and even fifty years.

In the Italian legal framework, the most relevant aspect introduced by the concession of valorization is the possibility to extend the concession period to as many as fifty years. In fact, and as stated in clause 4 of the Article 3-bis aforementioned, concessions are assigned through public and open procedures (calls for tenders) and implemented for a period of time to be defined not exceeding fifty years and consistent with the achievement of some degree of economic and financial balance.

\section{CONCLUSIONS}

\subsection{ICT for P3s}

The implementation of ICT tools in P3 agreements should strongly support the development of the operation throughout the entire process, especially so in concession operations.

A refined survey provides quantitative and qualitative evaluations of aspects linked to asset, property and facility management. It allows the elaboration of precise data and economic estimates referred not only to the present, but also projected over time by means of discounted cash flow analysis, in order to calculate the return of investment in a more accurate way.

Therefore, on the one hand the survey provides a technical base for the design, and on the other hand it provides a technical base for the economic estimate.

Besides, concerning long-term management, both public and private entities could monitor the maintenance costs and state of conservation of the entire property by means of the implementation of asset management information systems using BIM tools. An integrated use of the most advanced technologies in the field of 3D survey and the use of methods based on digital 3D modeling ought to be pursued.

This is why in partnership operations a specific person in charge of BIM should have a deep knowledge in real estate field, threedimensional modeling, information modeling, data management, identification of data base contents facilitating the choice of the best strategies for running a property, and Computerized Maintenance Management System (CMMS). Moving from an analogic organization to a digital one, he should take advantage of BIM in order to increase quality and increase profit (Manes, 2019).

\section{REFERENCES}

Acacia, S., Casanova, M., Dal Bò, A., 2014. ICT in the data management. Analysis of the wooden roof of Santa Maria Assunta della Pieve (Novi Ligure). In Della Torre, S. (ed.), ICT per il miglioramento del processo conservativo, Proceedings of the International Conference Preventive and Planned Conservation, volume 5, Monza, Mantova, 5-9 May, 223-232. Nardini Editore, Firenze.
Agenzia del Demanio, 2013. Concessioni di valorizzazione. Art. 3-bis D.L. n. 351/2001 convertito dalla L. n. 410/2001 e s.m.i. come recentemente modificato e integrato dal comma 308 dell'Art. 1, L. 24 di-cembre 2012, n. 228. Available at: http://www.ancicampania.it/demanio/images/doc/D_Concession i_Valorizzazione.pdf (accessed 11 March 2019).

Baratin, L., Bertozzi, S., Moretti, E., 2014. Tecnologia GIS per la manutanzione programmata dei beni culturali. In Della Torre, S. (ed.), ICT per il miglioramento del processo conservativo, Proceedings of the International Conference Preventive and Planned Conservation, volume 5, Monza, Mantova, 5-9 May, 73-81. Nardini Editore, Firenze.

Benatti, E., Borgarino, M. P., Della Torre, S., 2014. Planet Beni Architettonici. Uno strumento per la conservazione programmata del patrimonio storico-architettonico. In Della Torre, S. (ed.), ICT per il miglioramento del processo conservativo, Proceedings of the International Conference Preventive and Planned Conservation, volume 5, Monza, Mantova, 5-9 May, 13-26. Nardini Editore, Firenze.

Brumana, R., Oreni, D., Barazzetti, L., Banfi, F., Roncoroni, F., Previtali, M., Valente, R., 2014. Survey and HBIM of the Basilica di Collemaggio in L'Aquila for managing and planning conservation activities. In Della Torre, S. (ed.), ICT per il miglioramento del processo conservativo, Proceedings of the International Conference Preventive and Planned Conservation, volume 5, Monza, Mantova, 5-9 May, 97-111. Nardini Editore, Firenze.

Brumana, R., Della Torre, S., Oreni, D., Previtali, M., Cantini, L., Barazzetti, L., Franchi, A., Banfi, F., 2017. HBIM challenge among the paradigm of complexity, tools and preservation: The Basilica di Collemaggio 8 years after the earthquake (L'Aquila). International archives of the photogrammetry, remote sensing and spatial information sciences, XLII, 2W5, 97-104. doi.org/10.5194/isprs-archives-XLII-2-W5-83-2017.

Brumana, R., Della Torre, S., Previtali, M., Barazzetti, L., Cantini, L., Oreni, D., Banfi, F., 2018. Generative HBIM modelling to embody complexity (LOD, LOG, LOA, LOI): surveying, preservation, site intervention - the Basilica di Collemaggio (L'Aquila). Applied Geomatics, 10(4), 545-567. doi.org/10.1007/s12518-018-0233-3.

Ciribini, A., Mastrolembo Ventura, S., Paneroni, M., 2014. La metodologia BIM a sostegno di un approccio integrato al processo conservativo. In Della Torre, S. (ed.), ICT per il miglioramento del processo conservativo, Proceedings of the International Conference Preventive and Planned Conservation, volume 5, Monza, Mantova, 5-9 May, 1-11. Nardini Editore, Firenze.

Cori, R., Paradisi, I., 2011. Una ipotesi di lavoro: l'applicazione ai servizi del sistema dei beni culturali del Project Financing. In Leon, A., Verdinelli De Cesare, P. (eds.), Qualità dei bandi per l'acquisto di servizi nel sistema dei beni culturali. I servizi del sistema dei beni culturali: come interpretarli, combinarli, innovarli, qualificarli, volume 2, 41-52. Available at: http://www.svilupporegioni.it/site/sr/home/argomenti-dirilievo/semplificazione-amministrativa/scheda16002850.html (accessed 11 March 2019).

Della Torre, S., 2016. Interview conducted by the author on December 22, 2016 at the Politecnico di Milano. 
Heras, V., Vandesande, A., Cardoso, F., Van Balen, K., 2014. A value-based monitoring system to enhance the preventive and planned conservation process. In Della Torre, S. (ed.), ICT per il miglioramento del processo conservativo, Proceedings of the International Conference Preventive and Planned Conservation, volume 5, Monza, Mantova, 5-9 May, 63-72. Nardini Editore, Firenze.

Hodge, G., Greve, C., 2010. Public-Private Partnerships: Governance Scheme or Language Game?. The Australian Journal of Public Administration, 69(S1), S8-S22. doi.org/10.1111/j.1467-8500.2009.00659.x.

Macdonald, S., Cheong, C., 2014. The Role of Public-Private Partnerships and the Third Sector in Conserving Heritage Buildings, Sites, and Historic Urban Areas. The Getty Conservation Institute, Los Angeles.

Manes, C., 2019. BIM Consultant \& Construction Specialist Systema. Available at: https://www.systemasrl.it/le-professionidel-real-estate-articolo-di-costantino-manes-su-ilqi/ (accessed 11 March 2019).

Manzo, R., 2017. Interview conducted by the author on July 27, 2017 at the Italian State Property Agency in Rome.

Martin, L., 2016a. Making sense of public-private partnerships (P3s). Journal of Public Procurement, 16(2), 191-207. doi.org/10.1108/JOPP-16-02-2016-B002.

Martin, L., 2016b. Public Procurement Practice. Public-Private Partnership (P3): Facilities and Infrastructure, Guidance issued by the National Institute of Governmental Purchasing to state and local government procurement officials, 1-14. Available at: http://www.nigp.org/docs/default-source/NewSite/public-private-partnership-(p3)-facilities-and-infrastructure (accessed 11 March 2019).

Moioli, R., Boniotti, C., Konsta, A., Pili, A., 2018. Complex properties management: Preventive and planned conservation applied to the Royal Villa and Park in Monza. Journal of Cultural Heritage Management and Sustainable Development, Special Issue: Preventive and planned conservation approaches for built heritage management, 8(2), 130-144. doi.org/10.1108/JCHMSD-06-2017-0035.

Oreni, D., Brumana, R., Della Torre, S., Banfi, F., Barazzetti, L., Previtali, M., 2014. Survey turned into HBIM: the restoration and the work involved concerning the Basilica di Collemaggio after the earthquake (L'Aquila). ISPRS Annals of the Photogrammetry, Remote Sensing and Spatial Information Sciences, II-5, 1-7.

Rypkema, D., Cheong, C., 2012. Public-Private Partnerships and Heritage: A Practitioner's Guide. Heritage Strategies International, Washington.

World Bank Group, 2019. Assessing Value for Money of the PPP. Available at: https://pppknowledgelab.org/guide/sections/54-assessing-valuefor-money-of-the-ppp (accessed 11 March 2019). 